\title{
The Influence of Experiential Learning Model on Primary School Student's Creative Thinking Skills
}

\author{
Lutfi Asyari, Risma Nuriyanti, Dani Gunawan, Rajji K. Adiredja \\ Institut Pendidikan Indonesia \\ asyarilutfi25@gmail.com
}

\section{Article History}

accepted 05/11/2020

approved 10/11/2020

published 01/02/2021

\begin{abstract}
The students' skill in exploring creative ideas in writing is a problem that needs to be taken seriously. This happens because of the students' lack of creative thinking in exploring some ideas in words. The purpose of this research was to examine the effects of experiential learning model on primary school students' creative thinking skill. The method used quasi-experimental of non-equivalent control group design. The population of this research was a group of fourth grader students of Sekolah Dasar Labschool UPI (Labschool UPI Primary School) in total of 47 students and divided in to two separate classes, which were an experimental class and a control class. The results of this research revealed significant contrasts in post-test between an experimental class and a control class. The results concluded that the experiential learning model has significant effects on primary school students' creative thinking skill. Therefore, the experiential learning model is one of the solutions for teacher to develop students' creative thinking skill, especially in writing from the aspects of flexibility, fluency, originality and elaboration. Moreover, the outcome ideas were diverse, expressive and comprehensible.
\end{abstract}

Keywords: experiential learning model, creative thinking skill, primary school

\begin{abstract}
Abstrak
Kemampuan siswa dalam mengembangkan ide kreatif pada sebuah tulisan menjadi suatu permasalahan yang perlu diperhatikan secara serius. Hal tersebut berakibat pada rendahnya kemampuan berpikir kreatif siswa dalam menuangkan gagasan pada sebuah tulisan. Penelitian ini bertujuan untuk mengetahui pengaruh model experiential learning terhadap kemampuan berpikir kreatif siswa sekolah dasar. Metode yang digunakan adalah kuasi eksperimen dengan desain nonequivalent control group design. Populasi pada penelitian ini adalah siswa kelas empat di Sekolah Dasar Labschool UPI yang berjumlah 47 siswa dan terbagi ke dalam dua kelas yaitu kelas eksperimen dan kelas kontrol. Hasil penelitian menunjukkan terdapat perbedaan yang signifikan antara posttest kelas eksperimen dan kelas kontrol. Dari hasil tersebut dapat disimpulkan bahwa model experiential learning berpengaruh secara signifikan kemampuan berpikir kreatif siswa sekolah dasar. Dengan demikian model experiential learning dapat dijadikan salah satu solusi oleh guru untuk mengembangkan berpikir kreatif siswa terutama dalam menulis dari aspek kelenturan kelancaran, orisinalittas dan kerincian. Selain itu gagasan yang disampaikan juga variatif dan mengandung ide-ide kreatif yang menarik serta mudah dipaham oleh pembaca.
\end{abstract}

Kata kunci: model experiential learning, kemampuan berpikir kreatif, sekolah dasar

Social, Humanities, and Education Studies (SHEs): Conference Series https://jurnal.uns.ac.id/shes

p-ISSN 2620-9284

e-ISSN 2620-9292 


\section{PENDAHULUAN}

Berpikir kreatif merupakan cara berpkir yang original dan reflektf dan menghasilkan suatu produk yang kompleks (Tendrita, dkk, 2016). Kemampuan berpikir kreatif dapat dikembangkan melalui pembelajaran atau pendidikan. Pernyataan ini sesuai dengan rumusan dalam Undang-undang nomor 20 tentang Sistem Pendidikan Nasional Tahun 2003 menyatakan bahwa pendidikan nasional bertujuan untuk berkembangnya potensi siswa agar menjadi manusia yang beriman dan bertakwa kepada Tuhan Yang Maha Esa, berakhlak mulia, dan berkepribadian luhur, berilmu, cakap, kritis, kreatif, dan inovatif; sehat, mandiri, dan percaya diri, dan toleran, peka sosial, demokratis, dan bertanggung jawab. Pernyataan tersebut menunjukkan bahwa tujuan pendidikan bukan sekadar menciptakan lulusan yang memiliki predikat tamat belajar semata, tetapi lebih dari itu yaitu menciptakan lulusan yang berkualitas. Maka dari itu keterampilan berpikir kreatif sangat dibutuhkan dalam lingkungan kelas dan dapat dikembangkan melalui pendekatan pembelajaran secara kelompok maupun individu (Lucchiari, Sala, \& Vanutelli, 2019)

Pembelajaran yang dapat mengembangkan berpikir kreatif siswa salah satunya pada pembelajaran bahasa Indonesia yang sangat berkaitan dengan nilai seni ataupun kreatif, karena di dalam pembelajaran bahasa Indonesia terdapat hasil produk sastra. Untuk itu tidak dapat dihindarkan pembelajaran terhadap siswa dengan pengembangan potensi kreativitas. Hal ini sejalan dengan pendapat Hutabalian (2018) yang mengemukakan bahwa sastra merupakan bagian integral materi pelajaran di sekolah, sebagai suatu kreasi dan seni yang dapat menyentuh pribadi kehidupan manusia, menunjang keterampilan, meningkatkan pengetahuan, mengembangkan rasa karsa, serta membentuk watak. Karena sastra sesuai dengan sifatnya yang imajinatif dan dapat mengembangkan dan membangun potensi kreatif dalam diri (Knoeller, 2003).

Banyak penelitian yang meneliti tentang kemampuan berpikir kreatif. Elfiani (2018) mengemukakan bahwa dengan menerapkan pendekatan problem solving berpengaruh terhadap kemampuan berpikir kreatif siswa. Pada penelitian ini guru masih menjadi dominan dalam pembelajaran, terbukti terjadi penurunan performa ketika waktu pembelajaran dihabiskan untuk pertanyaan prosedural dan terarah kepada siswa. Untuk mengatasi hal tersebut perlu adanya pembelajaran yang tidak terfokus pada siswa, salah satunya dengan penggunaan media yang bisa menarik perhatian dan kinerja siswa. Lestari (2017) mengemukakan bahwa pembelajaran akan lebih efektif jika berbantuan media, terutama media gambar yang akan berpengaruh terhadap kemampuan berpikir kreatif siswa. Hal ini dibuktikan berdasarkan hasil statistik penggunaan media gambar dapat berpengaruh terhadap kemampuan berpiki kreatif siswa. Dalam upaya mengembangkan kemampuan berpikir kreatif siswa terutama dalam pembelajaran tidak berpatok pada pengunaan media saja akan tetapi bisa dilakukan dengan menerapkan model pembelajaran tertentu yang mampu memberikan pengalaman yang bermakna bagi siswa (Cheng, 2010).

Berkenaan dengan fakta lapangan dan studi literatur yang telah ditemukan peneliti mengenai kemampuan berpikir kreatif siswa sekolah dasar bisa dikatakan jauh dari harapan, diantaranya siswa masih kesulitan dalam mengembangkan ide kreatif, gagasan yang dihasilkan tidak variatif, tidak adanya penerapan metode atau model pembelajaran yang mengembangkan kemampuan berpikir kreatif. Hal tersebut 
melatarbelakangi dilaksanakannya penelitian kuasi eksperimen yang bertujuan untuk mengetahui pengaruh model experiential learning terhadap kemampuan berpikir kreatif siswa. Melalui penerapan model experiential learning yang berbasis pengalaman dan menumbuhkan makna belajar siswa diharapkan mampu mengembangkan reativitas siswa. Hal ini sejalan dengan pendapat Hosnan (2014, hlm. 351) bahwa pembelajaran yang menuntut berpikir kreatif siswa harus memperhatikan kebermaknaan dan pengalaman siswa dalam belajar baik secara individu maupun kelompok.

Tujuan dari penelitian ini adalah mengetahui pengaruh model experiential learning terhadap kemampuan berpikir kreatif siswa. sampel pada penelitian ini adalah siswa kelas empat siswa sekolah dasar yang berjumlah 47 orang. Pelaksanaan pembelajaran model experiential learning terdiri dari empat tahap yaitu concrete experience, reflection observation, formation of abstract concept and generalization, dan testing experimentation yang dilaksanakan secara berkelanjutan selama enam kali pembelajaran pada kelas eksperimen. Penelitian ini akan menjadi sebuah alternatif pembelajaran dalam mengembangkan kemampuan berpikir kreatif bagi siswa terutama guru sekolah dasar. Tidak hanya itu guru mendapatkan pengetahuan baru terkait penilaian kemampuan berpikir kreatif dari segi kelenturan, kelancaran, orisinalitas, kerincian.

\section{METODE}

Penelitian ini menggunakan pendekatan kuantitatif dengan metode penelitian kuasi eksperimen rancangan nonequivalent control group design. Penelitian eksperimen kuasi ini digunakan untuk mengetahui perbedaan kemampuan kelas yang diberi perlakuan dan kelas yang tidak diberi perlakuan. Menurut Sugiono (2016, hlm. 77 ), dalam penelitian ini akan terdapat dua kelompok yang tidak dipilih secara random. Keduanya kemudian diberi preetest untuk mengetahui keadaan awal dan perbedaan antara kelompok eksperimen dan kelompok kontrol. Hasil pretest yang baik adalah nilai kelompok eksperimen dalam kelompok kontrol tidak berbeda secara signifikan. Berikut gambaran dari desain penelitian tersebut tertera pada tabel 1

Tabel 1 Desain Penelitian Nonequivalent Control Group Design

$\begin{array}{lll}\mathrm{O}_{1} & \mathrm{X} & \mathrm{O}_{2} \\ \mathrm{O}_{3} & - & \mathrm{O}_{4}\end{array}$

Keterangan

$\mathrm{O}_{1} \quad$ : Preetest kelas eksperimen

$\mathrm{O}_{2} \quad$ : Posttest kelas eskperimen

$\mathrm{O}_{3} \quad$ : Preetest kelas kontrol

$\mathrm{O}_{4} \quad$ : Posttest kelas kontrol

$\mathrm{X} \quad$ : Perlakuan pembelajaran experiential learning

: kelas yang tidak diberikan perlakuan

Adapun populasi dalam penelitian ini adalah seluruh siswa sekolah dasar kelas IV di Kota Bandung. Sampel yang dipilih adalah siswa kelas IV SD Laboratorium Percontohan UPI Bumi Siliwangi yang berjumlah 47 siswa, 24 siswa dari kelas eksperimen dan 23 siswa dari kelas kontrol. teknik pemilhan sampel menggunakan teknik purposive sampling karena penelitian kuasi eksperimen terdapat dua kelompok yang tidak dipilih secara random (Sugiono, 2016). Ha tersebut diperkuat 
oleh pendapat Cresswell (2013) dan Crano, Brewer, \& Lac (2014) yang menyatakan bahwa kuasi eksperimen melibatkan penempatan partisipan tetapi bukan penempatan acak dalam kelompok karena eksperimen tidak dapat menciptakan kelompok secara artifisial untuk eksperimennya. Instrumen penelitian yang digunakan dalam penelitian ini adalah (1) Rencana Pelaksanaan Pembelajaran yang berbasis kurikulum 2013. Dalam kegiatan pembelajaran terdapat tahap-tahap model pembelajaran experiential learning untuk pembelajaran menulis narasi. (2) Tes tulis berupa intruksi untuk menulis karangannarasi yang dilaksanakan pada saat pretest dan posttest. Penilaian kemampuan berpikir kreatif diukur dengan rubrik penilaian kemampuan berpikir kreatif terhadap hasil karangan siswa yang diukur dari empat aspek yaitu (1) kelenturan; (2) kelancaran; (3) orisinalitas; dan (4) kerincian. Keempat aspek tersebut dinilai berdasarkan skala 1-5.

\section{HASIL DAN PEMBAHASAN}

Pada penelitian ini pembelajaran dilaksanakan enam kali pembelajaran. Sebelumnya siswa diberikan pretest untuk mengetahui kemampuan awal siswa baik di kelas eksperimen maupun di kelas kontrol. Kesamaaan kemampuan awal siswa dalam keterampilan menulis narasi menunjukkan tidak adanya keberpihakan peneliti dalam menentukan kelas eksperimen dan kelas kontrol. Dari hasil pretest didapatkan nilai rata-rata kemampuan berpikir kreatif siswa di kelas eksperimen adalah 42.50, sedangkan di kelas kontrol mendapatkan nilai rata-rata sebesar 44.56. nilai tersebut masih dikategorikan kurang. Hal tersebut dikarenakan pembelajaran baik di kelas eksperimen maupun kelas kontrol kurang kondusif yang berpengaruh terhadap kemampuan berpikir kreatif siswa. hal tersebut sejalan dengan pendapat Beyer (1993), Marzano, dkk, Semiawan, (1987) bahwa untuk menumbuhkembangkan kreativitas anak perlu adanya pengembangan iklim yang kondusif dalam pembelajaran dan mengubah strategi jika tujuan ingin tercapai.

Persamaan kemampuan awal siswa baik di kelas eksperimen maupun kelas kontrol menjadi alasan peneliti untuk memberikan perlakuan. Perlakuan yang diberikan kepada masing-masing kelas ini adalah perlakuan yang berbeda. Pada kelas eksperimen perlakuan yang diberikan yaitu menerapkan model experiential learning. Sedangkan pada kelas kontrol tanpa menerapkan pembelajaran secara konvensional. Pada tahap pemberian perlakuan ini siswa memperoleh pembelajaran sebanyak enam kali pertemuan. Setelah kedua kelas diberikan perlakuan yang berbeda, kemudian dilaksanakan tes akhir atau posttest. Setelah dilakukan posttest pada kedua kelas. Hasil posttest menunjukkan perubahan, nilai rata-rata kemampuan berpikir kreatif masing-masing kelas baik kelas eksperimen maupun kontrol mengalami kenaikan dibandingkan sebelumnya. Nilai rata-rata posttest kelas eksperimen yang di berikan perlakuan dengan menerapan model experiential learning adalah 77,29 , sedangkan kelas kontrol sebesar 52. 17. Perolehan nilai postest yang cederung meningkat disebabkan oleh adanya perubahan iklim kelas yakni proses pembelajaran yang kondusif di dua kelas yang dijadikan sampel penelitian. Peningkatan yang signifikan pun terlihat di kelas eksperimen yang menerapkan model experiential learning..

Berdasarkan hasil tersebut, untuk membuktikan hipotesis penelitian bahwa terdapat pengaruh model experiential learning terhadap keterampilan menulis narasi siswa dilakukan terlebih dahulu uji statistik yakni (1) uji normalitas data antara kelas ekperimen dan kelas kontrol, dari hasil uji normalitas baik pretest dan postest keduanya berdistribusi normal dengan nilai signifikansi $0.099>0.05$ pada data pretest dan $0.367>0.05$ pada data postest; (2) uji homogenitas antara kelas ekperimen dan kelas kontrol, dari hasil uji homogenitas baik pretest maupun kontrol keduanya memiliki varians yang homogen dengan nilai signifikansi data pretest 0.519 dan postest 0.95 , dan (3) uji hipotesis. Untuk uji hipotesis akan dijelaskan secara rinci pada tabel 2 
Tabel 2 . Uji Hipotesis

\begin{tabular}{lccc}
\hline Hasil & Df & Pretest & Posttest \\
& & & Sig.(2-tailed) \\
Kemampuan berpikir kreatif & 45 & 0.628 & 0.00 \\
\hline
\end{tabular}

Berdasarkan data pada tabel 3, menunjukkan nilai signifikansi pretest lebih dari 0.05 yakni 0.628 , maka dapat disimpulkan bahwa tidak terdapat prebedaan antara kelas ekperimen dan kelas kontrol. Berbeda dengan nilai signifikansi posttest kurang dari 0.05 yakni 0.00 , hal ini berarti posttest kemampuan berpikir kreatifsiswa di kelas eksperimen yang mendapat perlakuan dengan menerapkan model pembelajaran experiential learning dan kelas kontrol yang tidak mendapatkan perlakuan terdapat perbedaan atau terdapat pengaruh yang signifikan.

Berdasarkan hasil tersebut, ditemukan bahwa pemberian perlakuan dengan menerapkan model pembelajaran experiential learning berpengaruh terhadap kemampuan berpikir kreatif siswa. Hal ini sekaligus menjadikan temuan baru dan membuktikan salah satu teori yang menyatakan bahwa model experiential learning dapat mengembangkan ide kreatif siswa. Menurut Terry (2001) bahwa salah satu keuntungan dari model pembelajaran experiential learning yaitu mendorong dan mengembangkan proses berpikir kreatif. Dengan melatih keterampilan menulis narasi siswa, tidak secara langsung melatih kemampuan berpikir kreatif siswa. Belajar dari pengalaman mencakup keterkaitan antara berbuat dan berpikir (Mardana dalam Hosnan, 2016). Dalam proses pembelajarannya, siswa dituntut untuk menemukan ide baru dari segi judul maupun gagasan yang dituangkan. Hal tersebut diperkuat oleh pernyataan Hyun Ju Kim (2017) bahwa dengan pengalaman, siswa dapat menciptakan dan menjelaskan ekspresi baru dengan ide unik mereka sendiri. Proses berpikir kreatif tersebut terjadi ketika siswa menemukan pengalaman baru yang terjadi ketika proses pembelajaran. Di mana siswa mampu berpikir dengan terbuka dan mampu membimbing dirinya sendiri sehingga memotivasi siswa untuk menciptakan hal yang baru (Hosnan, 2014).

Melalui pembelajaran experiential learning siswa diberikan materi yang akan dipahami oleh siswa dengan pengalaman belajar dan kemudian diberikan tugas untuk menulis narasi dimana di dalam kegiatan tersebut terjadi proses berpikir kreatif siswa. Menurut Rahman (2018a) bahwa guru selaku pendidik harus mampu mengimplementasikan berbagai metode untuk menunjang ketercapaian siswa. Kondisi pada kelas eksperimen tentunya berbeda dengan proses pembelajaran pada kelas kontrol. Pembelajaran pada kelas kontrol lebih menekankan pada bagaimana siswa mampu menghasilkan teks narasi dengan kemampun berpikir kreatif yang baik tanpa disertai dengan suasana pembelajaran yang menunjang ketercapaian hasil belajar. Hal tersebut ditandai dengan proses pembelajaran yang masih berfokus pada guru. Di mana guru masih menjadi satu-satunya sumber belajar dan pemberi informasi.

Berdasarkan hasil temuan, nilai kemampuan berpikir kratif lebih tinggi dibandingkan keterampilan menulis narasi siswa. Hal tersebut disebabkan karena pada proses menulis narasi dibatasi oleh struktur dan aturan penulisan yang sudah baku sehingga tahapan pada experiential learning kurang memperhatikan pada hal tersebut. Sedangkan pada pada kemampuan berpikir reatif siswa, pengalaman-pengalaman bermakna yang sudah di alami siswa, mampu siswa tuangkan secara ekspresif ke dalam sebuah tulisan. Dari hal tersebut membuat siswa termotivasi untuk menciptakan ide baru yang variatif dan juga beragam tanpa adanya batasan apapun. Seperti yang diungkapkan Rahman, dkk (2018b) yang mengemukakan bahwa dengan adanya 
pengalaman pada diri siswa, siswa akan termotivasi menuangkannya dalam objek tulisan yang disertai ide baru yang beragam.

\section{SIMPULAN}

Berdasarkan hasil paparan di atas, maka dapat disimpulkan model experiential learning secara statistik memberikan pengaruh yang signifikan terhadap kemampun berpikir kreatif siswa sekolah dasar di kelas IV SD Laboratorium Percontohan UPI. Hal tersebut dibuktikan dengan uji hipotesis penelitian antara perbedaan posttest kontrol dan posttest eksperimen. Nilai signifikansi kurang dari 0.05 , yaitu sebesar 0.00 . Hal ini berarti nilai posttest kemampuan berpikir kreatif siswa di kelas eksperimen dan kelas kontrol terdapat perbedaan. Hasil tersbut bisa dilihat nilai rata-rata pretest eksperimen mendapat 42.50 mengalami kenaikan setelah diberikan perlakuan yaitu pada posttest menjadi 77.29. Sedangkan pada kelas kontrol nilai rata-rata pretest mendapatkan 44.56 mengalami kenaikan pada posttest yaitu menjadi 52.17. Maka dapat disimpulkan bahwa model pembelajaran experiential learning berpengaruh secara signifikanterhadap kemampuan berpikir kreatif siswa sekkaligus menjadikan temuan baru danmembuktikan teori yang menyatakan bahwa model experiential learning mampu mengembangan ide kreatif siswa yakni meliputi empat indikator yaitu kelenturan, kelancaran, orisinalitas dan kerincian.

\section{DAFTAR PUSTAKA}

Sukarata: UNS Press

Awang, H., \& Ramly, I. (2008). Creative thinking skill approach through problem-based learning: Pedagogy and practice in the engineering classroom. International journal of human and social sciences, 3(1), 18-23.

Aizikovitsh-Udi, E., \& Amit, M. (2011). Developing the skills of critical and creative thinking by probability teaching. Procedia - Social and Behavioral Sciences, 15, 1087-1091. doi:10.1016/j.sbspro.2011.03.243

Beyer, Barry K. 1993. Teaching Thinking Skills: A Handbook for Elementary School Teachers. Boston: Allyn and Bacon

Cheng, V. (2010). Teaching Creative Thinking in regular science lessons:Potentials and obstacles of three different approaches in an Asian context. Asia-Pacific Forum on Science Learning and Teaching, 11(1), Article 17, 1

Cresswell, J. W. (2013). Research Design: Pendekatan Kualitatif, Kuantitatif, dan Mixed. Yogyakarta: Pustaka Pelajar

Crano, W. D., Brewer, M. B., \& Lac, A. (2014). Principles and methods of social research. Routledge.

Elfiani, F. (2018). Upaya Meningkatkan Kemampuan Berpikir Kreatif Siswa Kelas Vii F Mts Ma'arif $\mathrm{Nu} 1$ Wangon Melalui Pembelajaran Ideal Problem Solving. AlphaMath: Journal of Mathematics Education, 3(2).

Feldhusen, J. F. (1995). Creativity: A knowledge base, metacognitive skills, and personality factors. The Journal of creative behavior, 29(4), 255-268.

Hamalik, O. (2001). Strategi pembelajaran. Jakarta: Djambatan

Hosnan, M.(2014). Pendekatan Saintifik dan Kontekstual Dalam Pembelajaran Abad 21.Bogor:Ghalia Indonesia dan Sastra

Hutabalian, F. A., \& Wasilah, A. (2018). Hubungan Berpikir Kreatif Dengan Kemampuan Menulis Teks Cerpen Siswa Kelas Xi Sma Negeri 5 Medan Tahun Pembelajaran 2017/2018. Basastra, 7(3), 184-194. 
Hyun-Ju Kim. (2017). The Effects of English Experiential Learning through Creative Thinking Activities. Studies in Linguistics, null(45), 457-481. doi:10.17002/sil..45.201710.457

Kolb, D. A. (2014). Experiential learning: Experience as the source of learning and development. FT press.

Kolb, Y. K. \& Kolb, D. A. (2009). The Learning Way Meta-Cognitive Aspects of experiential Learning. "Simulation \& Garning" Journal Sage Publication. 40(3), 297-327

Knoeller, C. (2003). Imaginative Response: Teaching Literature through Creative Writing. The English Journal, 92(5), 42. doi:10.2307/3650423.

Lestari, A.W, Pratiwi, Y. \& Mudiono, A. (2017). Peningkatan Kreativitas Menulis Narasi melalui Penerapan Model Rally Coach berbantuan Media Gambar untuk Siswa Sekolah Dasar. Jurnal Pendidikan: Teori, Penelitian dan Pengembangan. 9 (2), 1220-1225

Lucchiari, C., Sala, P. M., \& Vanutelli, M. E. (2019). The effects of a cognitive pathway to promote class creative thinking. An experimental study on Italian primary school students. Thinking Skills and Creativity, 31, 156-166.

Marzano, Robert J.; Brandt, Ronald S; Hughes, Carolyn Sue; Jones, Beau Fly; Presseisen, Barbara Z.; Rankin Stuart C.; and Suhor, Charles. (1993). Dimensions of Thinking: A Framework for Curriculum and Instruction. Virginia: ASCD.

Munandar, U. (1977). Creatvity and Education. A Study of The Relationship between Measure of Creative Thinking and a number of Educational Variables in Indonesian Primary and Junior Secondary School. Jakarta: Dep P \& K

Munandar, U. (2014). Pengembangan Kreativitas Anak Berbakat . Jakarta: Rineka Cipta

Nuryani, K. E. S. (2016). Pengembangan Siswa Melalui Pembelajaran Menulis di Sekolah Dasar. Lensa: Kajian Kebahasaan, Kesusastraan, dan Budaya, 6(1), 5467.

Rahman, dkk. (2018b). Writing Prose Through Think Talk Write Model BAsed On Video In Elementary School. Journal Of Language Studies

Rahman. (2018a). Literasi di Sekolah Dasar. Pendidikan Dasar. Universitas Pendidikan Indonesia

Sugiono. (2016). Metode Penelitian: Kuantitatif, Kualitatif, dan R\&D. Bandung: alfabeta

Tendrita, M, Mahanal, S \& Zubaidah, S. (2016). Pemberdayaan Keterampilan Berpikir Kreatif Melalui Model Remap Think Pair Share. Proceeding Biology Conference. 13(1). 285-291

Terry, M. (2001). Translating Learning Style Theory into University Teaching Practices: An Article Based on Kolb's Experiential Learning Model. Journal of College Reading and Learning, 32(1), 68-85.doi:10.1080/10790195.2001.10850128

Treffinger, D. J., \& Reis, S. M. (Eds.). (2004). Creativity and giftedness. Corwin Press. 